This item was submitted to Loughborough's Research Repository by the author.

Items in Figshare are protected by copyright, with all rights reserved, unless otherwise indicated.

\title{
DNA and the active criminal population
}

PLEASE CITE THE PUBLISHED VERSION

LICENCE

CC BY-NC-ND 4.0

\section{REPOSITORY RECORD}

Leary, Dick, and Ken Pease. 2019. "DNA and the Active Criminal Population". figshare. https://hdl.handle.net/2134/892. 


\section{DNA and the Active Criminal Population}

\section{Dick Leary and Ken Pease ${ }^{1}$}

Analysis of rates of submission of crime scene samples from one police force area and of matches with offender DNA samples already on the national database demonstrates, first, an increasing rate of submission, second, a steady state of matching in the West Midlands force during the period studied, at 58 per cent, and third, a reasonable linear fit between number of samples and number of matches, suggesting no diminution in return as the number of submitted samples increased. The results are discussed in terms of the distribution of lengths of criminal career; implications for practice are also discussed, especially the importance of taking criminal justice samples at the first presenting opportunity.

Key Words: DNA; forensic databases; criminal careers; prediction; evidence

\section{Introduction}

Crime science, in the sense used in the establishment of the Jill Dando Institute (hereafter JDI), seeks to integrate the contributions of applicable science in the service of crime reduction. Criminology is the (largely unloved) child of law, history, psychology and sociology, with the mixture varying substantially amongst its practitioners, as is all too evident from any of the editions of the Oxford Handbook of Criminology (of which the most recent is published as Maguire et al, 2002). Forensic science, being limited to the post-crime context, seeks to apply hard science to the identification of perpetrators. Forensic scientists scarcely ever cite criminologists, and criminologists return the favour. Further, while criminologists attend to both crime reduction and the processing of offenders, the application of hard science in the service of crime reduction tends to be partial, and predominantly to deal with the protection of large organisations against predation by crime. This can be inferred from the final report of the DTI Foresight Crime Panel (Department of Trade and Industry, 2001), and is obvious to those engaged in such work.

The vision attending the establishment of JDI requires the deployment of all relevant sciences in the service of crime reduction. Where does one start? One candidate strategy involves trawling the scientific literature for ideas about how animal and plant defences can be adapted for human use. This and other routes have been suggested by Ekblom (1999) and Leary (1997).

A complementary route whereby this integration may be advanced involves the connection of the criminal careers literature (a product of criminology) with national offender databases (a product of forensic science). In this paper we claim to do no more than scratch the surface of the issue, using data from the UK National DNA Database (NDNADB) on events occurring within the West Midlands Police Force area.

Each person who becomes criminally involved can be characterised by the length of time elapsing between first and most recent offences, the frequency of offending, and the distribution of crime types according to type and seriousness. Taken together, these variables can be referred to as a 
'criminal career'. The present note should be regarded as an attempt to establish a connection between criminal careers and DNA sampling, specifically by demonstrating the link between the number of crime scene sample submissions (known as DNA crime scene stains) and the number of resulting matches with samples taken from individuals (known as criminal justice samples) on the NDNADB, using data over a 19-month period from one police force area (West Midlands).

Eschewing normal practice, we will anticipate our conclusions at this early point. The data presented below shows that the number of crime scene stains submitted by West Midlands Police over the period increased by an average of some 19 per month, that the proportion of submitted samples resulting in matches does not change over the period, but that the linear link between the number of submissions and the number of matches suggests no diminution in matching rates as the number of submissions increases. The important aspects of these results are that:

- There is no increase in the proportion of crime scene samples matched over time. This is to be expected because the churn rate of criminal careers is high (see for example Farrington, 2002) so that many of those on the NDNADB no longer offend, and many of those who do offend have embarked on their career so recently as not yet to appear on the NDNADB. This (assuming that a total-population DNA database is not yet acceptable) emphasises the importance of taking criminal justice samples at the first available opportunity, perhaps at the time of an official caution. It highlights the need to remain realistic over the shortness of time for which most of those contributing criminal justice samples will remain relevant for crime detection purposes. The usefulness of the NDNADB does not necessarily increase with its size, but with the proportion of those recently identified as offenders who are included.

- $\quad$ For every 100 crime scene samples taken in the West Midlands, we can expect some 58 matches, which is surprisingly high—substantially higher than national figures.

- There is no strong sign of diminishing returns in rates of match as the number of submitted samples increases. This is consistent with the notion of a fast-changing population of active offenders. There is no case, other than the economic, for limiting submission of crime scene samples at current levels, since increases in submissions have hitherto yielded a prorata increase in matches.

- $\quad$ As a general principle, deriving from the broad criminal career literature rather than from the work reported here, criminal justice and crime scene sampling should be generic and not limited to certain categories of crime. Such research indicates strongly that chronic offenders commit a wide range of crimes and do not in general limit themselves to any particular category of criminal activity (see Farrington, 2002 and Leary, forthcoming). Committed offenders are generalists, with a dash of specialisation. Accounts of practitioners confirm that offenders sampled for shop-theft often match against crime stains for burglary, sex crimes and offences against the person, and vice-versa (this is an area where formal research is needed).

\section{Data}

Information was supplied by West Midlands Police concerning the number of submissions of crime scene DNA samples and the number of matches with criminal justice samples on the NDNADB, for the period from April 2000 to October 2001. This represents a total of 6878 submissions and 3982 matches. Figure 1 shows the number of submissions per month, exhibiting a steady increase of some 19 per month over the period. 
Figure I. Number of crime scene samples submitted by West Midlands police, April 2000-October 200 I

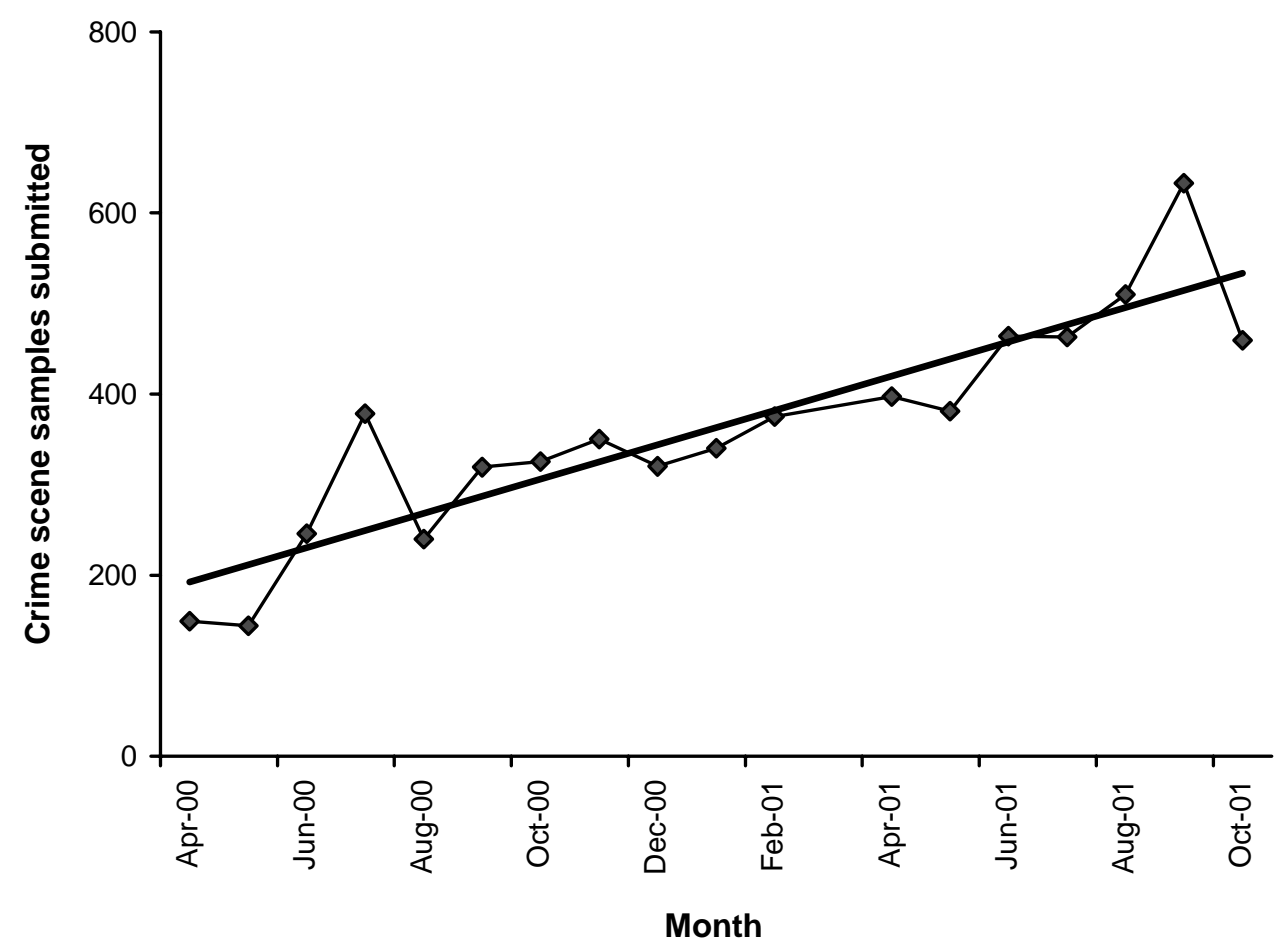

The next question concerns the proportion of submitted samples which are matched with NDNADB samples over time. The link between time and proportion matched is presented as Figure 2. This excludes the outlier for March 2001, where the number of matches was almost 200 higher than in any other month; speculatively, this may be an effect of the end of the financial year, with a backlog of samples being matched and billed.

Figure 2. Proportion of crime scene samples matched by month

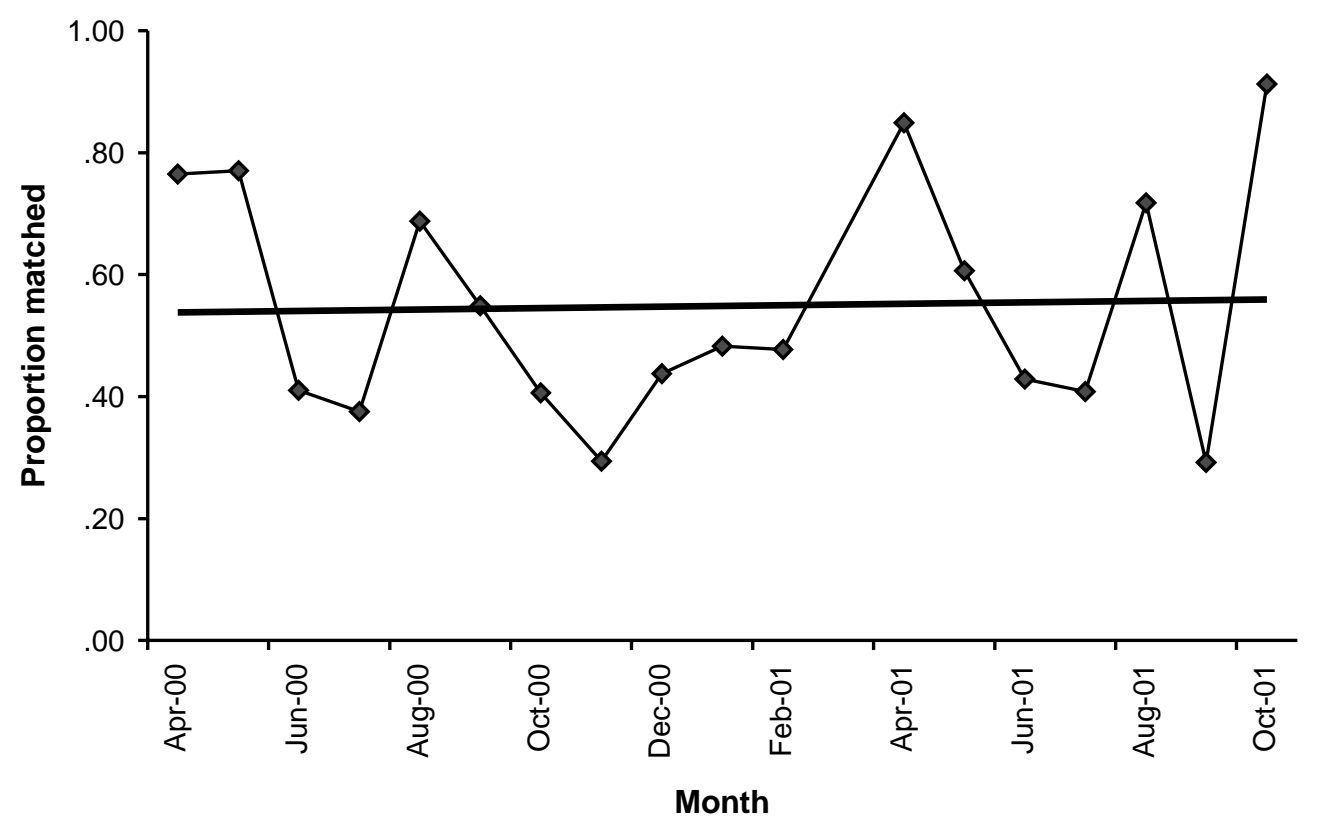


It will be seen from Figure 2 that the proportion matched does not change over time, as shown by the line of best fit. This might be thought surprising in that the size of the NDNADB increases steadily, so that the proportion of the active offender population covered should increase. The provisional explanation for this pattern is the churn rate of active offenders, with many entering and leaving criminal careers every year. It would be interesting to look at the matched proportion of submitted samples over the early years of the NDNADB, since there should at that stage have been an association between the size of the database and the proportion matched.

The next question concerns the link between the number of samples submitted and the proportion matched. Figure 2 looks at the link between month and match rate, neglecting the number of crime scene samples submitted during the month, which fluctuated around a general upward trend (see Figure 1). There are two ways of looking at the link between samples submitted and proportion matched. First, as submission becomes less selective, it could be argued that the proportion of matches should decline apace, in that the samples submitted under a selective submission policy should be the more promising. When the less promising are also sent, matches should proportionally decline. The second (more parsimonious) view is that every rise in submissions yields a proportionate rise in matches. Figure 3 shows the association between number of samples submitted and proportion matched. A linear fit $\left(R^{2}=0.46\right)$ suggests that each extra submission across the range will yield 0.74 matches. This conclusion is extremely tentative, and is included only to illustrate ways in which data of this kind can be analysed. The plot is not visually impressive, and the line is as it is because of three months with exceptionally high rates of submission. The issue needs to be kept under review as the number of submissions increases. The important point is that, however the plot is interpreted, it remains inconsistent with the notion of diminishing returns with increased submission of crime scene stains.

\section{Figure 3. Number of scene sample submissions by number of matches}

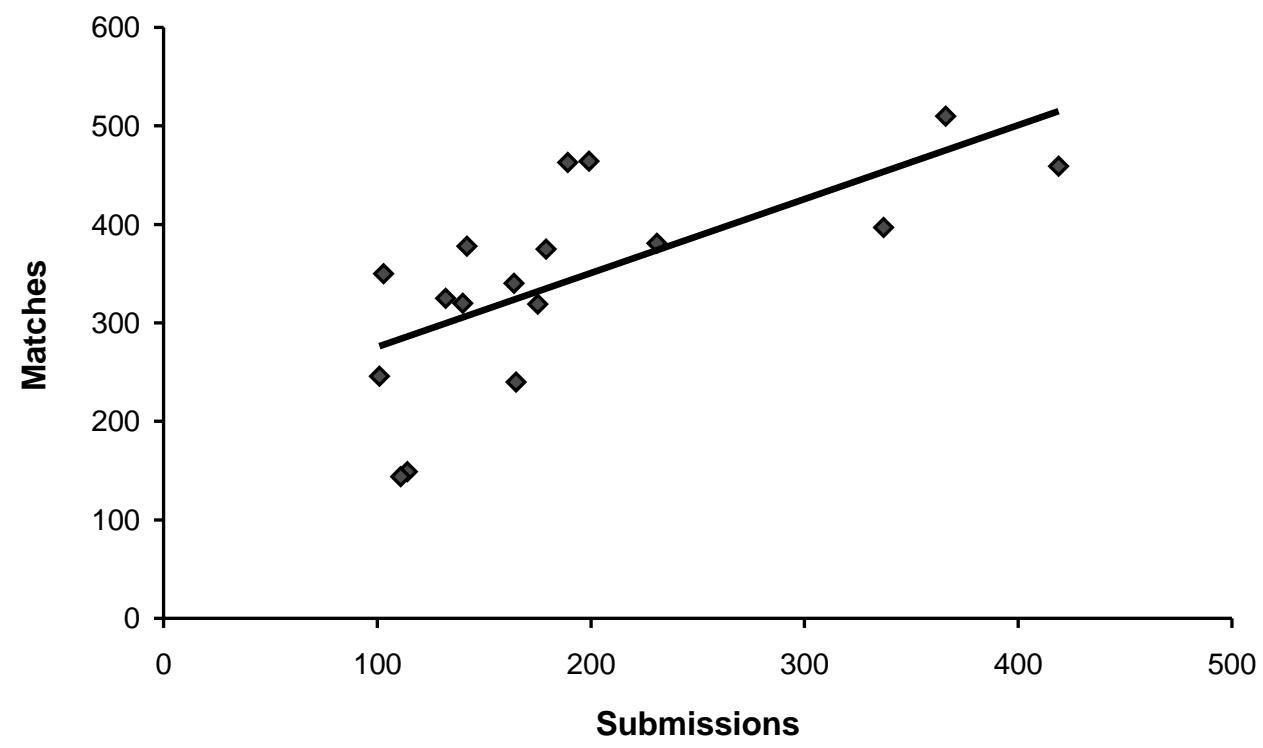

Discussion

There are important practical implications of even such a crude analysis as that undertaken here. First, it emphasises that forensic analysis should be informed by our understanding of criminal 
careers to calculate likely benefits. Specifically, it reinforces the importance of the liberal taking of criminal justice samples at the first opportunity, regardless of the crime committed or alleged. Since criminal careers are typically short, the useful life of the average entry on the NDNADB is also short, so there should be an emphasis on the earliest possible entry of an offender onto the database. Given the rate at which offenders embark upon criminal careers, the proportion of matchable samples from crime scenes will always fall short of one, and may already have asymptoted to the levels reported in the analysis above. This is a fact of life given the trajectories of criminal careers.

The second practical implication is that there is as yet no marked sign of diminishing returns from extra submissions of crime scene samples, at least in the West Midlands. Repeated analyses must be undertaken to clarify the point at which this ceases to be true. Historical analysis should be undertaken to show the trajectory of matching rates to clarify how they have increased. The first entry on the NDNADB, like the first fax machine, was virtually useless. How matching rates have increased (and will in time level off) gives clues about how testing should be deployed to make the best use of criminal career information.

Aligning the processes of collecting DNA from suspects and scenes, as well as submitting the samples swiftly to the NDNADB, could result in maximising matches (where 'swiftly' here means as early as possible in the career of the criminal and submission to the NDNADB as early as possible). Issues for additional consideration here are the extent to which DNA is shed by individuals in the course of committing crime, the yield from DNA stains and the effectiveness of sensing devices employed to detect the presence of DNA and then to collect it at the scene. At a strategic level, each DNA match should be considered as providing investigators and intelligence analysts with at least two opportunities:

- They can formulate a hypothesis that the suspect may have had the opportunity of committing the crime concerned.

- They can formulate a second hypothesis: that the suspect may have committed other offences, thereby justifying the search for additional evidence to either substantiate or negate the hypothesis. Additional evidence here could be other forensic contact trace material, witness testimony about other crimes, or admissions about other offences offered by the suspect to 'clear their slate'.

Finally, it is important to stress that a match is not a conviction. One well-placed commentator described DNA matching as a fresh filling placed between two slices of stale bread. By this was meant that while the science may be good, police operations and training (the first stale slice) and the vicissitudes of prosecution and conviction (the second stale slice) limit the quality of the whole sandwich experience. Tilley and Ford (1996) stress this need to contextualise DNA developments within police and court process. The truth of this, however, in no way affects the conclusions reached above.

A next step in the integration of criminal career research and the NDNADB might be the application of mark-recapture methods used to estimate the size of animal populations (see Sutherland, 1996). For example, ringing a given number of birds and checking the proportion of them on later recapture which have been ringed allows estimation of the total bird population. Taking a criminal justice DNA sample is in this context equivalent to ringing, and the proportion of those sampled who are later linked to crime scenes is in many ways equivalent to bird recapture. There are technical issues about the technique which need to be addressed, but it certainly affords one avenue of advance. Another such avenue would comprise formal mathematical modelling of what would be expected of matching rates under varying assumptions about criminal careers and police sampling of crime scenes, an enterprise on which Michael Townsley and the second author have just embarked. 
Crime Prevention and Community Safety: An International Journal

\section{Notes}

1 Dick Leary, MBE and Ken Pease, OBE are both in the Jill Dando Institute of Crime Science, University College London; email: rmleary@aol.com. The authors wish to thank Inspector Rick Adderley of the West Midlands Police and Dr Michael Townsley of Liverpool University for their help and advice during the preparation of this paper.

\section{References}

Department of Trade and Industry (2001) Turning the Corner. Final Report of the Foresight Crime Panel. London: DTI.

Ekblom, P. (1999) Can We Make Crime Prevention Adaptive by Learning from Other Evolutionary Studies? Studies in Criminology and Crime Prevention. Vol. 8, No. 1, pp 27-51.

Farrington, D.P. (2002) Key Results from the First Forty Years of the Cambridge Study in Delinquent Development. In Thornberry, T.P. and Krohn, M.D. (eds) Taking Stock of Delinquency: An Overview of Findings from Contemporary Longitudinal Studies. New York: Kluwer/Plenum.

Leary, R.M., Barclay, D. and Rankin, B. (1997) Using Forensic Science Effectively. Home Office, ACPO and FSS Study. London: HMSO.

Leary, R.M. (forthcoming) UK National Intelligence Model and Forensic Led Intelligence System: Connecting the Dots. The International Journal of Police Science and Management.

Maguire, M., Morgan, R. and Reiner, R. (2002) Oxford Handbook of Criminology. 3rd edn. Oxford: Clarendon.

Sutherland, W.J. (ed.) (1996) Ecological Census Techniques: A Handbook. Cambridge: Cambridge University Press.

Tilley, N. and Ford, A. (1996) Forensic Science and Crime Investigation. Crime Detection and Prevention Paper No. 73. London: Home Office. 